\title{
MENGIKUTI PROGRAM KERJA KECAMATAN
}

\author{
EKA SERLI PRATIWI \\ 9173770410318 \\ ekaserlipratiwii@gmail.com
}

1. Bentuk Kegiatan

$>$ Mengikuti Program Kerja Kecamatan.

2. Lokasi

> Hutan Pinus Paccumikang Desa Jenetallasa.

3. Hari/Tanggal dan Waktu

> Kamis, 29 oktober 2020 - Minggu 01 november 2020 pukul 10:15 - selesai.

4. Peserta yang Dilibatkan

> Kepala Camat Rumbia dan Bangkala

> Dosen STIE/STKIP Yapti Jeneponto

> Mahasiswa KKLP Yapti Jeneponto.

> Karang Taruna Kecamatan Rumbia

> Beberapa Lembaga Komunitas

> Masyarakat Desa Jenetallasa

$>$ Pengunjung 
5. Alasan Diadakannya

> Alasan diadakannya kegiatan ini adalah melihat kecamatan Rumbia ini sangat banyak tempat yang bisa dijadikan sebagai objek wisata, salah satunya di desa Jenetallasa tepatnya di hutan pinus paccumikang dapat menarik minat pengunjung untuk berwisata ke tempat ini. Selain tempatnya yang indah juga cuacanya yang dingin sehingga cocok dijadikan sebagai tempat untuk berlibur akhir pekan bersama teman maupun keluarga.

6. Tujuan dan Manfaat

> Tujuan utama dilakukannya kegiatan ini yaitu sebagai pemenuhan Program Kerja Kecamatan KKLP Yapti Jeneponto Kecamatan Rumbia. Selain itu, dikegiatan ini kita juga bisa mendapatkan pengalaman dan teman baru.

7. Deskripsi Kegiatan

> Kegiatan ini berlangsung selama 3 hari. Acara pembukaannya di buka oleh Bupati Jeneponto atau yang mewakili pada tanggal 31 oktober dan acara penutupannya di tanggal 1 november oleh wakil Bupati Jeneponto. Ditutup dengan senam bersama pengunjung. 